Working Papers No. 101/07

\title{
Was Dick Whittington Taller Than Those He Left Behind? Anthropometric Measures, Migration and the Quality of Life in Early Nineteenth Century London
}

\author{
Jane Humphries \\ \& \\ Tim Leunig
}

(C) Jane Humphries \& Tim Leunig

London School of Economics 
Department of Economic History London School of Economics Houghton Street London, WC2A 2AE

Tel: $\quad$ +44 (0) 2079557860

Fax: $\quad$ +44 (0) 2079557730 


\title{
Was Dick Whittington Taller Than Those He Left Behind? Anthropometric Measures, Migration and the Quality of life in Early Nineteenth Century London? ${ }^{1}$
}

Jane Humphries \& Tim Leunig

\begin{abstract}
Using a new source of evidence we explore the geographical mobility of mid-nineteenth century seamen. Among seamen born outside London, the tall, the literate and those who could remember the exact day, month and year when they were born - characteristics that we suggest mark them out as men with more choices in life - were more likely to migrate to London. Contrary to what might be inferred from contemporary descriptions of urban disamenities or from persistent differentials in mortality, London appears as a desirable destination for those who could choose. The conclusion must be that London was not so bad, and we should adjust our perception of the problems of urbanisation accordingly, with implications for the wider debate on the standard of living during the industrial revolution. The paper's methodological innovation is the use of height as an explanatory variable in the analysis of migration. Although correlated with other variables that are routinely used in anthropometric studies to indicate life chances, such as literacy and the ability to recall date of birth, height has many advantages over these alternatives in that it exhibits higher levels of significance, and is more flexible. Moreover while literacy and heaping are in essence binary variables, height is a (near) continuous one, and one that allows us to test for linear and non-linear responses, as we do with interesting results in this paper. Perhaps the most fruitful use of height in historical analyses may turn out to be as an explanatory variable; at the very least such a research strategy provides anthropometric historians with fresh opportunities.
\end{abstract}

\footnotetext{
${ }^{1}$ We would like to thank Greg Clark for supplying us with his parish location dataset, Humphrey Southall for supplying us with the population data (via the Essex data archive) and Judith Allen for painstakingly entering the data from microfilm. We also thank the National Archives for supplying the data so efficiently. This paper developed from work that we presented to seminar audiences in Oxford and Cambridge, and conference audiences at the Keio Conference on anthropometrics and the Helsinki International Economic History Conference. Participants at those seminars and conferences, as well as Dudley Baines, Chris Minns and Leonard Schwarz provided helpful comments. All remaining errors are ours alone. We thank the British Academy for paying for the data copying and entry and the Japanese Government Ministry of Education Grant-in-Aid and Keio Economic Society for funding attendance at both conferences.
} 


\section{Introduction}

Dick Whittington is a character familiar to most British people, as the hero of a well-loved children's story. In the tale, the young Dick, accompanied by his cat, travels from Gloucester to London believing that its streets are paved with gold. When things go badly he is tempted to return home, but, on leaving the city he hears the bells of London ringing. To him they say, "Turn again Whittington, three times Lord Mayor of London". Heartened, he does go back, and after a series of adventures the prophecy comes true. Dick marries his sweetheart Alice, makes a fortune and becomes Lord Mayor of London three times. The story, like most folklore, has a basis in fact for there was indeed a Richard Whittington, who was born in Pauntley Gloucestershire in the 1350s, did migrate to London, became an apprentice, and later a master, a rich man, and Lord Mayor of London, not three, but four times!

In migrating Whittington did what many had done, and many more would do in the centuries that followed: move to a large city, and, in particular, to London. Modern analyses of migration have been heavily influenced by Ravenstein's pioneering work on the published censuses of 1871 and 1881 which gave rise to his "laws" of migration (Grigg, 1977). While Ravenstein famously hypothesized that most nineteenth-century migration was over short distances, he also suggested that migrants going longer distances tended to go to one of the great centres of commerce or industry. Drawing on the 1851 census, Anderson found that $54 \%$ of the British population lived more than 2 kilometres from their place of birth, with those moving to the cities moving particularly far: $80 \%$ of migrants to London had been born at least 26 kilometres away (Anderson 1990). Thus Anderson's and other studies confirm the propositions that while many people moved, migration was often only over short distances, but that those who moved to London and other important urban labour 
markets moved much further on average. (Anderson, 1990, Boyer 1997, Boyer and Hatton, 1997).

Although some people would have migrated from towns to the countryside, the pattern was primarily the other way, for this was an era in which Britain changed from being a predominantly rural to an increasingly urban society. In 1750 , at the start of the industrial revolution, $21 \%$ of the English population lived in towns of 5000 or more inhabitants. By 1800 that figure had grown to $28 \%$. This total may not sound dramatic, but it accounted for more than half of all European urbanisation in this period (Wrigley, 2004, pp. 89-90). The speed of urbanisation accelerated further in the first half of the nineteenth century, with the growth rates of urban areas increasing from $2.7 \%$ in the late eighteenth century to $3.2 \%$ in the early nineteenth century, before falling back to around $2 \%$ in the late nineteenth century (Wrigley 2004, table 3.11 p. 88, Baines and Woods 2004 table 2.3, p. 44). The early nineteenth century, the era with which this paper is concerned, thus represents the peak period for urbanisation in English and Welsh history. Understanding who migrated is therefore an important historical question.

The source of urbanisation was not a decline in the numbers employed in agriculture, since these remained roughly constant from 1600 until 1840. But given the rise in total population, a constant number of workers in agriculture implies a declining agricultural share of the workforce, in this case from around 55\% in 1700 to $40 \%$ in 1800 and $25 \%$ in 1850 (Wrigley 2004, p. 90). The rise in the number of non-agricultural workers is not a sufficient condition for urbanisation, but it does permit it, since unlike agricultural work, manufacturing and service jobs were geographically more flexible. It was the economies of scale and agglomeration in what we now call "the industrial revolution" that increasingly concentrated manufacturing in factories, and concentrated those factories in towns and cities. With that concentration came a 
concentration of services that support manufacturing, such as merchants, ports, and docks, as well as of personal services, such as retailing, and, of course, domestic service.

Migration within Britain is therefore an important aspect of British history. Yet its study even for the nineteenth century, relatively rich in documentation, has been limited by the data available (Whyte, 2004). One obvious question is: who moves? The published census returns allow large-scale, comparative analyses (Long and Ferrie, 2003; Long, 2005). The census enumerators' books from 1841 onwards provide detailed information on moves over the life course between birthplaces and places of current residence, with some information on intermediate moves forthcoming from the birthplaces of children. The migration histories of individuals can be explored in more detail by linking entries in the census enumerators' books for successive censuses but the number of definite linkages that can be made tends to be small relative to the effort involved (Pooley and Turnbull, 1998). Accounts of the movements of individuals and families can be constructed on the basis of diaries, memoirs and genealogies (Pooley and D'Cruze, 1994). Although these give migration a human face, such findings may not be representative and again require painstaking research effort. Our focus is on a particular social and occupational grouping within which we seek to predict which individuals were most likely to migrate to London.

This question bears not only on an understanding of migration, but also on an understanding of the standard of living in London. Any number of contemporaries - from Marx and Engels to Dickens and Gaskell graphically depicted the squalor and brutality of life in large cities in the early nineteenth century, a judgement supported empirically for London by John Landers in his book Death and the Metropolis (1993). But against this many historians suspect that life in rural areas could also be unpleasant. Not all diseases of filth and underfeeding were predominantly 
urban; tuberculosis for example was at least as prevalent in some rural areas (Woods and Shelton, 1997). Most importantly, perhaps, in rural areas wages were certainly lower (Hunt, 1986) and (a theme emphasized in this paper) opportunities for economic and social mobility fewer.

All things considered was life in London so bad that only those with few choices migrated there? Or did the advantages outweigh the costs, so that, even if not paved with gold the streets of London were on balance attractive? If we found that those who migrated to London generally had more life choices than those who stayed behind, then we would be able to conclude that the differentials on pay and, perhaps, on opportunities, were more than sufficient to compensate for the urban disamenities. London would be pulling the talented rather than passively receiving the dispossessed and desperate. In Peter Clark's terminology (1972) migrants would be in search of "betterment". But if in contrast we found that those who migrated had attributes correlated with fewer life opportunities, then we would be forced to conclude that these people were pushed out of their own communities by changing economic conditions. To again use Peter Clark's (1972) terminology, they arrived in London desperate for "subsistence".

\section{The Role of Anthropometric History in Explaining Migration}

Anthropometric history, the use of physical measurements such as height to investigate living standards historically, has generated much interest, some excellent books, including but not limited to Floud et al Height, health and history (1990), Komlos, Stature, living standards and economic development (1994) and Steckel, Backbone of history (2002), and a large number of scholarly articles. It continues to be an important part of economic and social history, generating new insights that would not otherwise be available. 
We have argued elsewhere (Leunig and Voth, 2003; Humphries and Leunig; 2007) that anthropometric history as well as adding to our understanding of secular trends in whole populations, can also illuminate variations within already well-studied populations for which data are often available only at an aggregate level. The most important contribution of anthropometric evidence in this context may be to examine the extent, nature and causes of differences within groups. For example, Nicholas and Steckel (1991) used heights not only to track trends in the heights of English convicts transported to Australia before 1840, but also to compare the heights of English and Irish convicts. Horrell et al (1998; 2001) used height to capture the effect of growing up in a female-headed household, Voth and Leunig (1996), and Oxley (2003) look at the effects of disease, and Humphries and Leunig (2007) on the effect of urbanisation. Steckel has shown not only that slave children were short in general but that owners varied nutrition levels according to their perception of the likely future value of slaves relative to the cost of feeding them now (2006). All of these are examples of issues that affect one person or group rather than another, as opposed to capturing secular trends in the economy as a whole.

Anthropometric studies have shown that height is a measure responsive to conditions that are specific to individuals as well as to groups. Thus, for example, those growing up in female headed households were, on average, shorter, than those who grew up in the same place and at the same time, but with two parents in the household. In addition, anthropometric history shows that height is consistently wellcorrelated (positively) with literacy, and (inversely) with "heaping", that is recording own age in round numbers, reflecting an inability to recall precise date of birth. In all of this, height captures early quality of life which in turn has an important role in determining a person's life chances. 
Until now, anthropometric history has concentrated on trying to explain height. We argue that height can be used to explain other observed outcomes. In early nineteenth century Britain height was almost always a desirable characteristic in and of itself, particularly for men: many jobs required strength (Samuel, 1977), and strength is correlated with height. But in addition anthropometric history has shown that height is well-correlated with other aspects of a child's upbringing that predict later success, such as literacy. In essence, then, the tall are likely to do better in life both because they are tall per se, and because being tall reflects a favourable upbringing. As such, height is a suitable proxy for life-opportunities, and can be placed on the right hand side of regression analysis when we want to explain whether a particular action was more common among those with good life opportunities, or more common among those with fewer life opportunities. If we found, for example, that people in a particular town, entering a particular profession that had no particular height or strength requirements were taller than the average for that town, it would be legitimate to conclude that that profession was desirable: the tall, who have more choices, chose it. In this case we will ask ourselves whether those who moved to London were taller than those who did not. If they were, we will argue that the compensating differentials available in London were sufficient to make London attractive, if migrants were shorter than non-migrants our conclusions on the quality of life in London will be more pessimistic.

In order to do this it is important to ensure that the people we are considering could have worked either where they were born (or somewhere of similar size) or in a larger place to which they could migrate. It would not make sense to study an occupationally heterogeneous group, since it may be that the tall enter a particular profession, which, for whatever reason, is more or less prone to requiring migration. Similarly an industry with industry-specific human capital that 
becomes more geographically concentrated will cause migration of a type we are less interested in. We need a profession that allows people to stay where they are, or to move. There are many such professions, including most aspects of the building trades, printers, postal workers, those involved in retail and distribution, and domestic servants. In contrast, geographically concentrated professions such as textile workers, coal miners, or white collar jobs, such as civil servants, found exclusively in big cities, would be less suitable for this sort of analysis. There are, to the best of our knowledge, no height surveys of building workers or domestic servants, but we do have good height data on merchant seaman in the early nineteenth century. Seamen were overwhelmingly born and brought up on or near the coast. They had, therefore, almost without exception the ability to work where they were born, or nearby. Equally, they could move to places far larger - Bristol, Southampton, Hull, Grimsby, Liverpool, and, of course, London itself. By restricting ourselves to seamen, we abstract from questions about whether the reason the tall are moving to London is because the tall are well-educated and moving to London to take up jobs such as those in government and the law. Our dataset is made up of people who, as far as we can tell, are similar to each other: they are all merchant seaman, they all, in some sense, have the opportunity to live in London, or to not live in London.

\section{The Data}

The data for our seamen are given in the Admiralty and Board of Trade's General Registry and Record Office of Seamen's "Register of Seamen's Tickets". 546,000 surviving records, preserved on 273 reels of microfilm, are held at the United Kingdom National Archives, under reference BT113. The Registry was created as an answer to the Admiralty's persistent concern as to how men could be raised speedily for 
the Royal Navy in emergencies. Impressment had been the main method but it was viewed with increasing distaste as time went on. The First Lord of the Admiralty, Graham, began a scheme that aimed to persuade merchant seamen to volunteer for service in the Royal Navy in the event of war (Bartlett, 1963). The Merchant Seamen's Registration Acts 1844 (7 \& 8 Vict c. 112) were designed to create lists of seamen that could be used in wartime as the basis for a ballot. The law stated that no British merchant seamen could leave the United Kingdom except with a Register Ticket, which would only be issued in person. The Acts were not particularly successful, with impressment continuing to be used, and were replaced in 1853 with a new form of registration (Bartlett, 1963).

The tickets included a fairly detailed physical description of each seamen, so that they would find it hard to evade service with the Royal Navy if that were required of them. The tickets include the seaman's name, date and place of nativity, their age, their height (measured to the nearest quarter of an inch), a physical description including their hair colour, deformities, tattoos and so on, whether they could write, the date at which they first went to sea, and, critically for our purposes, their place of birth and their place of residence when unemployed. Places of birth and residence were generally recorded in a similarly detailed fashion usually to the level of the parish or town, sometimes to the street or even the house.

The first 20 reels of microfilm were duplicated and entered into a database. These reels contain 39901 observations. We exclude illegible entries, those born before 1801, those whose heights were not recorded (one recording officer simply wrote "growing" on every entry, no matter the age), those whose recorded ages are inconsistent with their given dates of birth (we allow a one year margin of error), and those whose place of birth or residence could not be traced conclusively, or were outside England and Wales. 
The latitude and longitude of each English and Welsh parish has been ascertained by Greg Clark (1998). No equivalent data exist for Scotland, hence we restrict ourselves to England and Wales. Of course there is always a degree of discretion in assigning a parish to a particular point. Parishes are not always of regular shape, and there will be parishes that could be assigned to a slightly different latitude and longitude. Some seamen gave a town rather than a parish as their place of birth or residence. In those cases where this could not readily be traced using the Clark dataset, we used the modern OS Gazetteer to find its location. Both datasets give locations to the nearest kilometre. Having found the location of the place of birth and residence a simple application of Pythagoras' theorem gives us the distance migrated. We use crow flies distances, neglecting issues such as the curvature of the earth, estuaries, mountains and the like. The loss of precision is very small. Furthermore, we matched Clark's parish dataset with that of Southall, which gives us the population of every place in every year from 1801 (using interpolation between census years). This allows us to include prior experience of big cities in our analysis of who moves to London.

Table 1. Summary Statistics about here.

\section{Analysis and Results}

The analysis is essentially very simple. We have a dataset that consists of people who are in many ways very similar. They are all male, they were all born in the same era, all aged 20 to 44, they are all merchant seaman and within this group we restrict our attention to those who were born outside of London. Some migrate to London, and some do not. We now investigate whether we can explain the decision to migrate in terms of the individual characteristics of each seaman. 
There are six potentially useful variables that we know for each seaman that we would expect to explain the decision to migrate to London. The first is the distance of the place of birth from London. Clearly the further the person is born from London, the less likely it is that they will migrate. The cost of doing so is likely to be higher, their knowledge of London and its opportunities are likely to be lower, and so on. Second, the person's age: since we are not measuring migrating in the previous year, but whether the person has migrated to London since birth, we can expect age to be positively correlated with the decision to migrate. Third, we have three variables that capture a person's likely life chances: height, literacy and the inability to remember your date of birth precisely. The last is termed age-heaping and is generally taken to mean the inability to remember even the exact year of birth - a disproportionate number of people in census records, for example, give a year of birth ending in a zero (Mokyr, 1983; Long, 2005). All the cases in our sample have a date of birth that matches their age. Some, however, are able to give only the year of birth, while most give their exact birthday. We use heaping in this context, therefore, to describe those who could remember the year but not exact date of birth. The first two are positively correlated with a better quality upbringing, the third is correlated with a worse quality upbringing. If London was, taken as a whole, a desirable place to live, we would expect the tall, the literate, and those able to remember their date of birth precisely to be more likely to migrate to London. If, in contrast, London was a less desirable place to live, we would expect that group of people who can out-compete the short, the illiterate and those who cannot remember their date of birth in any particular labour market - to remain in the provinces, while those less fortunate end up moving to London because of the absence of sufficient jobs in more desirable locations. Finally, we include the population of the place of birth. It may be that 
London held fewer terrors for those who grew up in large places and knew something of life in a large urban area.

The decision to migrate to London is a classic binary variable: either the seaman concerned has moved to London at the time of their registration card, or they have not. For that reason we use probit regression as our means of analysis. Two of the explanatory variables are also binary: literacy and the inability to remember date of birth. In equation one, the remaining variables are entered linearly: distance from London, age, height and population in place of birth. Since we generally know the exact date of birth and the exact date of ticketing, we are able to enter age precisely. Height, as we mentioned, is measured to the nearest quarter of an inch. The average seaman was 5 feet 5.97 inches tall, with a standard deviation of 2.38 inches.

Table 2 about here. Results

Regression 1 performs well. All of the coefficients are correctly signed, and all are significant at at least the $10 \%$ level. The predicted rate of migration is within $2.5 \%$ of the actual level. As we would expect, the variables for distance and age are powerful explanators. Those who were born the mean distance from London - 216 kilometres - were around 17 percentage points less likely to migrate to London than those living on the outskirts of the city. Age also mattered: every additional year increased the chance of having moved to London by $1.3 \%$. The three variables that aim to capture a person's life chances are consistently signed in that the signs on literacy and height are the same, and opposite to the sign on the heaping variable. There are two types of conclusions that we can draw at this stage, about history, and about methodology. In terms of our understanding of history, given that the signs on literacy and height are positive, and that the sign on the heaping variable is negative, we can 
conclude that on average seamen thought that the benefits of living in London outweighed the costs. Second, in terms of methodology we can see two ways in which the height variable performs better than either the literacy or the heaping variable. The co-efficient on height is significant at the $0.1 \%$ level, while the coefficients on literacy and heaping are significant only at the $10 \%$ level. This is a potentially important result for anthropometric historians, because it suggests that variation in heights may be a more powerful explanatory variable than other life experience variables with which height is correlated. In addition, whilst literacy and heaping are somewhat crude binary variables, height is a (near) continuous variable. In this case the co-efficient on height suggests that a one standard deviation rise in height increased the propensity to migrate by the same amount as the ability to write, while a two standard deviation fall in height reduced the propensity to migrate by about the same amount as the inability to remember the date of birth.

The non-binary nature of the height variable is such that we can investigate linear and non-linear effects of changes in heights. In equation two we do this by dividing the sample into three categories by height, small, average, and tall. The intuition for this is the same as entering height and height squared in the regression, but has the advantage that the coefficients are easy to interpret. Average is defined as those within one standard deviation of the mean, small and tall are those outside of this range. Average is the omitted category in the regression.

Again, the regression performs well. As we would expect, all of the co-efficients on the variables other than height are essentially unchanged in magnitude and significance. But now a more nuanced picture about the role of height emerges: compared with being average, being tall mattered, whereas being small did not. The coefficient on tall implies that those more than 1 standard deviation taller than the mean $-17 \%$ of the sample - were $6.4 \%$ more likely to migrate to London. Those 1 standard deviation 
or more shorter than the mean $-14 \%$ of the sample - were $2.2 \%$ less likely to move, but this result is not significant even at the $10 \%$ level. Other formulations of the equation give the same result: being tall is always significant, being short, however defined, is never significant at any conventional level of significance, although it is always correctly signed and approaching the borders of significance.

In this context $6.4 \%$ is not a small number. On average $37.5 \%$ of seaman born outside of London migrated to the capital. This figure can be broken down arithmetically into the probabilities for different height groups. The probability that one of the $83 \%$ of seamen who were of average or below average height migrating to London was $36.4 \%$, but the probability that one of the $17 \%$ of seamen who were more than 1 standard deviation taller than the mean migrating to London was $42.9 \%$, that is to say, the tall were $18 \%$ more likely to migrate to London than those who were not tall.

Having ascertained that the tall were more likely to move to London, we can also ask ourselves whether, conditional on migrating, the tall were more likely to migrate further. In this case the dependent variable is distance migrated, and therefore we use an OLS regression.

Table 3: How far did different groups migrate, about here

Again, the distance from London is a significant determinant of how far people who migrated moved. Indeed, given the high proportion of all migrants that migrated to London, this result was inevitable. Similarly, age is a positive and statistically significant predictor of migration distance from birth: this is good evidence that people migrated steadily away from their place of birth, over time, and reinforces the notion of a fluid society, but not one in which people move randomly, but instead predominantly move progressively away from their place of birth. The variable on the 
size of place of birth is again positive. In this case this reflects the fact that migration was almost always to a place of significant size. In that such places are generally separated by at least moderate distances, those who migrated from a large town had, therefore, to go a considerable distance to reach the next large town. Some of those born in rural areas could, in contrast, migrate to a large town without travelling far.

What is striking, however, is that none of the quality of early life variables - height, literacy or heaping - are statistically significant at conventional levels. Furthermore, although height and heaping are correctly signed relative to each other and to our prior expectations in the light of table 2, literacy is wrongly signed. We have therefore found that whilst variables that capture the quality of life in early years, and correspondingly suggest degrees of opportunity later in life, do affect the decision as to whether to migrate, they do not affect the distance migrated once the decision to migrate has been made.

\section{Discussion}

Is it credible that people who could have chosen not to live in London - and the tallest $17 \%$ of sailors clearly fell into this group - would have chosen to do so? It is hard for historians to reconcile the descriptions of the vileness of life in the metropolis with its apparent attractions to immigrants, for London's growth in the seventeenth, eighteenth and nineteenth centuries illustrates yet another of Ravenstein's "laws": large towns grew more by migration than by natural increase (Grigg, 1977). Indeed for much of the early modern period mass immigration was needed to compensate for the high death rate in the capital. Why did migrants come when moving to London put them at risk of an early grave? Although the city's death rate had fallen by the first 
quarter of the nineteenth century, and immigration had perhaps slowed down, London continued to attract large numbers of migrants (Schwarz, 1992, pp.237-8). The motive to migrate is usually studied in terms of "push" and "pull" factors, respectively factors that forced people to leave the countryside such as rural unemployment or expropriation and factors that attracted people to the cities such as higher wages and more opportunities for advancement. Peter Clark's analysis of migrants in early modern England uses a similar dichotomy comparing migration for "subsistence", that is to keep body and soul together with migration for "betterment" that is in the hope of social and economic advancement (Clark, 1972, pp.134-150). While subsistence migration was probably very important to London's growth in the sixteenth century, and the metropolis remained a focus for the poor and desperate, by the eighteenth and nineteenth centuries there seems little doubt that "betterment" was a more likely motive for the majority of migrants (Earle, 1994), a conclusion consistent with our finding for the sample of seamen. It was men with advantages (height, literacy and numeracy) who were most likely to move to the capital. Why?

London's large community of sailors provides a particularly interesting context for studying the motives for migration. Since many had been born and brought up either in the city's maritime parishes or in seaside communities elsewhere, particularly on the east-coast of England and Scotland, sailors' origins are held to have been strikingly different from those of most migrants to London (see Earle, 1994, pp. 74-5). A much higher proportion of sailors came from counties at some distance from London such as Northumberland and Devon. Many more came from outside England and Wales as well. Indeed sailors from all over the world made their homes in east London (Earle, 1994, p. 75). Why did these immigrant sailors choose to live in London, where rent and other 
expenses were probably much higher than in their native places, and when they could have set sail from the places in which they were born?

Sailors would not have had to live in London all year, since they would have been on board ship for much of the time. That said, it is easy to overstate the proportion of time spent aboard. Many journeys were short, and many nights would have been spent ashore even when work was regular, let alone when it was not. So what were the attractions of the metropolis for these particular men?

One obvious attraction was London's relatively higher wages, and although the economy of London was changing in the first half of the nineteenth century, in many trades it retained its advantages. But the metropolis's advantages here were not so clear cut for mariners who sold their services on a national, indeed international market. For seamen residence made no difference to pay rates unless it cut a man off from the main coastal and international trade routes. This was not the case for east coast sailors who would have got London rates whatever port they shipped from (Earle, 1994, p. 75). The main economic advantage of London was not the pay, but the vast range of ships using the port since the metropolis dominated the coastal trade and some two-thirds of England's imports and exports passed through its docks (Earle, 1994, p. 75). As Peter Earle has argued, for the majority of sailors who worked the coastal trades and short haul routes to Europe, the problem was to put together sufficient voyages to accumulate a decent annual income, a problem more easily solved from London than from Teeside or Plymouth (Earle, 1994, p. 76).

As well as providing a deep and developed market for sailors' berths, London also offered many attractions to sailors when ashore. Leonard Schwarz describes seamen as "the major 'tourist' industry of the Port of London and as important to the east end economy as the aristocracy was to Westminster" (Schwarz, 1992, p. 109). To the obvious 
entertainment, should be added some less transparent benefits. Earle (1994) points out the importance of employment opportunities for the wives of mariners. Intermittent employment and slow payment of wages meant that many sailors' families relied on contributions from women and children to survive. Equally important were the opportunities afforded the sailors themselves when out of sea service, many of which suited their skills: river transport and loading and unloading ships for example (Schwarz, 1992, p. 109).

But London was attractive not only for the options it offered for minimising periods of unemployment and for supplementing sea wages. Most important of all, and here Dick Whittington catches our eye once more, was its opportunity for advancement. As the historian of London's labour market notes, for those with ambition it was always "the place to be" (Schwarz, 1992, p. 2). Seafaring might disproportionately have attracted men with ambition.

According to Ralph Davis a seaman had much better chances of moderate promotion, which might at least double his pay, than most town artisans or rural labourers (Davis, 1962). With perseverance and capacity a seaman might even become a master. The merchant service offered one of the "few avenues from the lowest to the middle ranks of society in England before the twentieth century" (Davis, 1962, p. 151). There was "a long ladder of ranks, the possibility of accumulating a little capital in the higher of them to assist the last step to the highest, and the rapid and almost continuous growth of the industry, were all to the advantage of the able, ambitious and sober man" (Davis, 1962, p.151). Thus one important intangible advantage of a career at sea, an advantage undoubtedly maximised in the capital's labour market and sought out with more assiduity by more confident (and taller) young men was the chance of upward mobility. 
Examples of men who took advantage of the opportunity to advance can readily be found among mariners' memoirs. These ambitious men tracked Whittington: upward mobility inevitably contingent on a move to London. Thus James Choyce, a sailor from a little earlier than our time period, grew up in a farming family outside London. But "seeing no better prospect than to follow the plough all the days of my life" ambitious James aged sixteen headed for London where he bound himself apprentice in the Southern Whale Fishery, symbolically sailing in the ship "London" (Choyce, 1891, p. 3). Choyce became a master mariner and the captain of a whaler. Similarly Henry Blewett, whose father was registered according to the Acts, went to sea originally in the Cornish fishing fleet, but eventually moved to London and rose up the ladder described by Davis (above). Blewett too eventually became a master mariner and captain of several important ships (Parsons and Parsons, 1993)

Some of the attractions of London spelled out above are specific to seamen. Other studies of different occupational groups are required to see to what extent London's advantages in terms of higher wages, greater employment opportunities, more leisure options and more chances for advancement, can be generalised. Moreover our finding that height works better than literacy and heaping as a predictor of "betterment" migration may well also be specific to a job like the merchant service where physical capability had value in and of itself (in addition to serving as a measure of background, confidence, contacts, etc). It seems probable that height would decrease in importance relative to literacy for jobs for which physical strength was less important. A really interesting profession - for men and women - in this context would be domestic service. But, alas, the data necessary to test this proposition for male and female domestic servants is unlikely to become available. 


\section{Conclusion}

This paper allows us to draw two types of conclusion: methodological, and historical. Our methodological conclusions are clear, unambiguous and potentially very exciting for those who work with anthropometric data: height works as an exogenous variable in regression analysis. It is capable of explaining as well as being explained. It offers some inherent advantages in comparison with obvious "competitor" variables such as literacy and age heaping, because height is a (near) continuous variable, rather than a binary variable. As such it facilitates more sophisticated and nuanced analyses of the effect of social background and upbringing on decisions. In this case we also found that height worked better, in the econometric sense of generating higher levels of statistical significance than competitor variables. This finding may be population specific: that height mattered more for seamen than did (say) literacy does not prove that height mattered more than literacy for all occupations. Much more work is needed - and warranted - in this area.

In historical terms we have found that the tall were more likely to migrate to London than those who were short or of average height. Given that the tallest $17 \%$ of seamen certainly had a wide range of job opportunities, this tells us that, notwithstanding its obvious, apparent and very real problems, in their eyes London appeared an attractive place in the early nineteenth century. This is an important finding in terms of understanding the quality of life in cities in this era. But it is also important more generally. As we noted at the start, urbanisation is a major aspect of the British industrialisation experience. If cities were awful, our interpretation of trends in the standard of living needs to be correspondingly pessimistic. But if cities were actually desirable places, then we can be more optimistic about the standard of living in Britain during the Industrial Revolution. 
Anthropometric history always claimed to be capturing something broader than just income levels. By showing that height works on the right hand side of an equation in a similar manner to, but more effectively than, literacy or age-heaping we have endorsed anthropometric historians' claim that stature is a useful encompassing measure of the quality of life during early years. And in showing that height is capable of explaining an issue such as migration, we think that we have identified some new and interesting avenues for anthropometric historians to explore. 
Bibliography

Anderson, M., 1990., the social implications of demographic change. In:

F.M.L. Thompson (Ed.), The Cambridge social history of Britain, 1750-1950. Cambridge University Press, Cambridge, 1-71

Baines, D.E., Woods, R., 2004., Population and regional development., In: Floud, R., Johnson P. (Eds.), The Cambridge economic history of modern Britain. Volume II: Economic maturity, 1860-1939.

Cambridge University Press, Cambridge., 25-55

Bartlett, C.J., 1963. Great Britain and sea power 1815-1853. Clarendon, Oxford..

Boyer, G.R., 1997. Labour migration in southern and eastern England, 1861-1901. European Review of Economic History 1 (2), 191-215. Boyer, G.R., Hatton, T.J., 1997. Migration and labour market integration in late nineteenth-century England and Wales. Economic History Review 50 (4), 697-734.

Choyce, J., 1891. The log of a jack tar; or the life of James Choyce, Master Mariner. Fisher Unwin, London.

Clark, P., 1972. The migrant in Kentish towns, 1580-164. In P. Clark, P. Slack (Eds.), Crisis and order in English towns, 1500-170. Routledge and Kegan Paul, London, 117-163.

Clark, G., 1998. The Charity Commission as a source in English economic history. Research in Economic History, 18, 1-52.

Davis, R.,1962. The rise of the English shipping industry in the $17^{\text {th }}$ and $18^{\text {th }}$ centuries. David and Charles, Newton Abbott.

Earle, P., 1994. A city full of people. Methuen, London.

Floud, R., Wachter, K., Gregory, A., 1990. Height, health and history. Cambridge University Press Cambridge.

Grigg, D., 1977. E.G. Ravenstein and the 'Laws of Migration'. Journal of Historical Geography 9, 41-54. 
Horrell, S., Humphries, J., Voth, H-J., 1998. Stature and relative deprivation: female-headed households in the industrial revolution. Continuity and Change 13, 73-115.

Horrell, S., Humphries, J., Voth, H-J., 2001. Destined for deprivation: human capital formation and inter-generational poverty in nineteenth-century England. Explorations in Economic History, 52, 339-65.

Humphries, J, Leunig, T., 2007. Cities, market integration and going to sea: stunting and the standard of living in early nineteenth century England and Wales University of Oxford Discussion Paper in Social and Economic History forthcoming.

Hunt, E.H., 1986. Industrialisation and regional inequality: wages in Britain, 1760-1914. Journal of Economic History 46, 936-66

Komlos, J., (Ed)., 1994. Stature, living standards and economic development. Chicago University Press. Chicago.

Landers, J., 1993. Death and the metropolis: studies in the demographic history of London, 1670-1830. Cambridge University Press Cambridge.

Leunig, T., Voth, H-J., 2003. Height and the high life: what future for a tall story? In P. David M. Thomas (Eds.), The Economic Future in Historical Perspective. Oxford University Press, Oxford, 419-438.

Long, J., 2005. Rural-urban migration and socioeconomic mobility in Victorian Britain. Journal of Economic History, 65 (1), 1-35.

Long, J., Ferrie, J.P., 2003. A tale of two labor markets: career mobility in the UK (1851-81) and US (1850-80). Paper presented at the Economic History Society Annual Conference, Durham, April.

Mokyr, J., 1983. Why Ireland starved. George Allen and Unwin, London. Nicholas, S., Steckel, R., 1991. Heights and living standards of English workers during the early years of industrialization, 1770-1815. Journal of Economic History 51, 937-57. 
Oxley, D., 2003. 'The seat of death and terror': urbanization, stunting and smallpox., Economic History Review 56 (4), 623-656.

Parsons, J., Parsons, N., 1993. Cornish fisher boy to Master Mariner. The life of Henry Blewett, 1836-189-. Bournmouth Local Studies Department, Bournemouth.

Pooley, C.G., D'Cruze, S., 1994. Migration and urbanization in northwest England, c.1760-1830. Social History 19, 339-358.

Pooley, C.G., Turnbull, J., 1998. Migration and mobility in Britain since the eighteenth century. UCL Press, London.

Samuel, R., 1977. Workshop of the world: steam power and hand technology in mid-Victorian Britain. History Workshop 9, 6-72

Schwarz., L., 1992. London in the age of industrialisation: entrepreneurs, labour force and living conditions, 1700-1850. Cambridge University Press, Cambridge.

Steckel, R., 1986. A peculiar population: the nutrition, health and mortality of American slaves from childhood to maturity. Journal of Economic History 46, 721-41.

Steckel, R., 2002. The backbone of history. Cambridge University Press, Cambridge.

Steckel, R., 2006. A pernicious side of capitalism: The Health of American Slaves. mimeo.

Voth, H-J., Leunig, T., 1996. Did smallpox reduce height? stature and the standard of living in London, 1770-1873. Economic History Review 49, 541-60.

Whyte, I., 2004. Migration and settlement. In C. Williams (Ed.), A companion to nineteenth-century Britain. Blackwell, Oxford, 273286.

Woods, R., Shelton, N., 1997. An atlas of Victorian mortality. Liverpool University Press, Liverpool. 
Wrigley, E.A., 2004. British population during the 'long' eighteenth century, 1680-1840. In Floud, R., Johnson P., (Eds.), The Cambridge economic history of modern Britain. Volume I Industrialisation, 1700-1860. Cambridge University Press, Cambridge, 57-95. 
$\underline{\text { Table } 1 \text { Summary Statistics }}$

\begin{tabular}{|l|l|l|l|}
\hline & In London & Outside London & Total \\
\hline Born & $30.8 \%$ & $69.2 \%$ & 15503 \\
\hline $\begin{array}{l}\text { Resident when } \\
\text { unemployed }\end{array}$ & $53.1 \%$ & $46.9 \%$ & 15503 \\
\hline & Born in London & $\begin{array}{l}\text { Born outside } \\
\text { London }\end{array}$ & Average \\
\hline $\begin{array}{l}\text { Percentage } \\
\text { migrating }\end{array}$ & $14.8 \%$ & $49.8 \%$ & $32.6 \%$ \\
\hline $\begin{array}{l}\text { Percentage } \\
\text { migrating to } \\
\text { London }\end{array}$ & - & $37.5 \%$ & - \\
\hline $\begin{array}{l}\text { Average } \\
\text { migration } \\
\text { distance, } \\
\text { conditional on } \\
\text { migrating }\end{array}$ & $87.8 \mathrm{~km}$ & $172.0 \mathrm{~km}$ & $161.5 \mathrm{~km}$ \\
\hline
\end{tabular}

We restrict ourselves to those aged 20 or over, that is, to those who were fully grown. "In London" defined as within 10 kilometres of Blackfriars.

"Migrating" means a place of residence $10 \mathrm{~km}$ or more from the place of birth

Source: National Archives BT113 reels 1-20, see text. 
Table 2. Results: Were the Tall More Likely to Move to London?

\section{Equation 1}

.dprobit ue__10km_from_blackfriars_born_dist_from_blackfriars_km_ age_calc heaping_only_birth_yr_known write_blank__no_

total_height_inches born_increm_1to10 if born__10km_from_blackfriars_ $==0$ \& age_calc $>20$

Iteration 0: $\log$ likelihood $=-7090.1171$

Iteration 1: $\log$ likelihood $=-6673.1384$

Iteration 2: log likelihood $=-6671.9593$

Iteration 3: $\log$ likelihood $=-6671.9592$

Probit regression, reporting marginal effects

Number of obs $=10715$

LR chi2(6) $=836.32$

Prob $>$ chi2 $=0.0000$

Log likelihood $=-6671.9592$

Pseudo R2 $=0.0590$

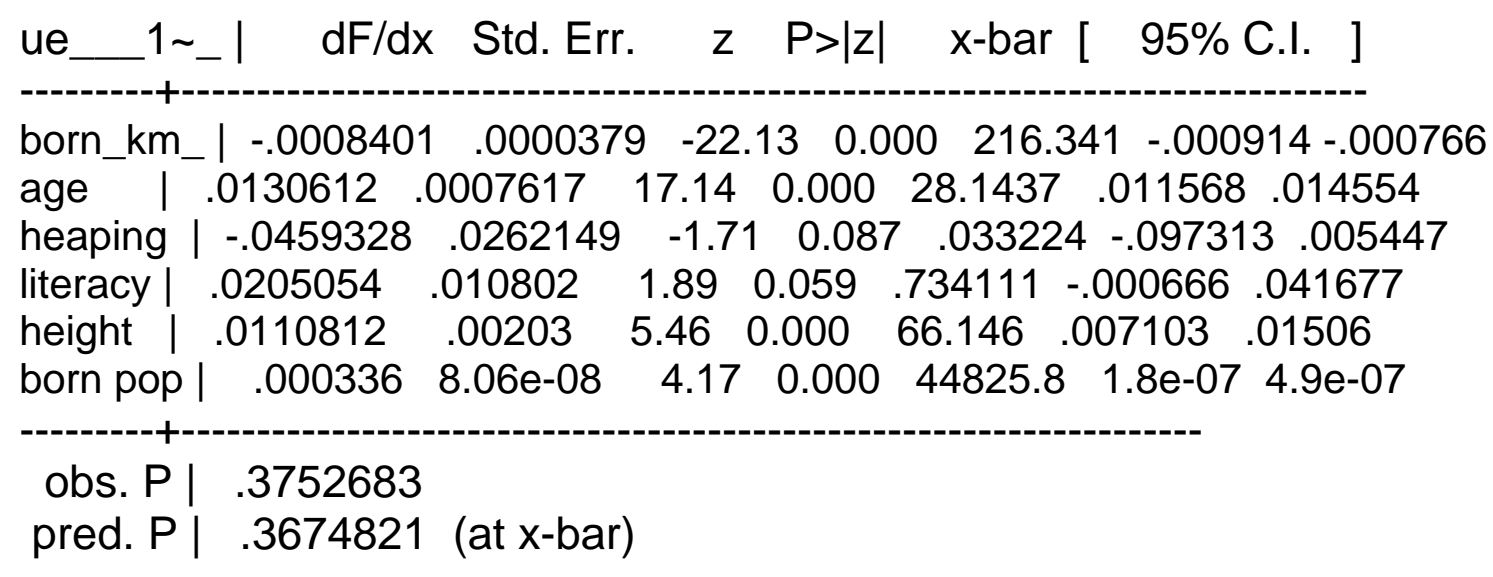

$\left.{ }^{*}\right) \mathrm{dF} / \mathrm{dx}$ is for discrete change of dummy variable from 0 to 1

$\mathrm{Z}$ and $\mathrm{P}>|\mathrm{Z}|$ correspond to the test of the underlying coefficient being 0

born $\mathrm{km}=$ distance of place of birth from London, in $\mathrm{km}$

age $=$ exact age, to the day when known

heaping $=$ not knowing exact date of birth

literacy = ability to write

height $=$ height in inches

born pop $=$ population within $10 \mathrm{~km}$ of place of birth, thousands 
Table 2. Results: Were the Tall More Likely to Move to London?

\section{Equation 2}

dprobit ue__10km_from_blackfriars_born_dist_from_blackfriars_km age_calc heaping_only_birth_yr_known write__blank__nno_tall short born_increm_1to10 if born__10km_from_blackfriars_ $==0$ \& age_calc $>20$

Iteration 0: $\log$ likelihood $=-7090.1171$

Iteration 1: $\log$ likelihood $=-6672.3655$

Iteration 2: log likelihood $=-6671.1926$

Iteration 3: $\log$ likelihood $=-6671.1925$

Probit regression, reporting marginal effects

Number of obs $=10715$

$\mathrm{LR}$ chi2(7) $=837.85$

Prob $>$ chi2 $=0.0000$

Log likelihood $=-6671.1925$

Pseudo R2 $=0.0591$

ue__1 _l dF/dx Std. Err. z P>|z| x-bar [ 95\% C.I. ]

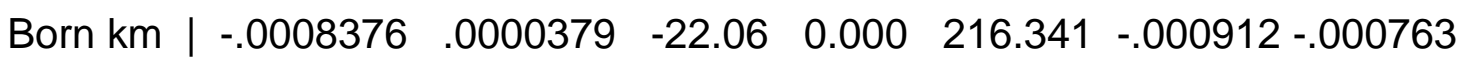

\begin{tabular}{l|llllllll} 
Age & | & 0130833 & .0007618 & 17.17 & 0.000 & 28.1437 & .01159 & .014576
\end{tabular}

Heaping | $\begin{array}{llllllll}.0456199 & .0262156 & -1.70 & 0.089 & .033224 & -.097002 & .005762\end{array}$

literacy | $\begin{array}{llllllll}0.0203073 & .010804 & 1.87 & 0.061 & .734111 & -000868 & .041483\end{array}$

tall $\quad \begin{array}{lllllll}.0648081 & .0130893 & 5.02 & 0.000 & .061722 & .039153 & .090463\end{array}$

short $\mid \begin{array}{llllllll}0.0218189 & .0139699 & -1.55 & 0.121 & .137471 & -.049199 & .005562\end{array}$

born pop | $\quad .000332 \quad 8.07 \mathrm{e}-08 \quad 4.12 \quad 0.000 \quad 44825.8 \quad 1.7 \mathrm{e}-07 \quad 4.9 \mathrm{e}-07$

obs. P | .3752683

pred. P | .3675074 (at x-bar)

$\left(^{*}\right) \mathrm{dF} / \mathrm{dx}$ is for discrete change of dummy variable from 0 to 1

$\mathrm{Z}$ and $\mathrm{P}>|\mathrm{Z}|$ correspond to the test of the underlying coefficient being 0

born $\mathrm{km}=$ distance of place of birth from London, in $\mathrm{km}$

age $=$ exact age, to the day when known

heaping $=$ not knowing exact date of birth

literacy = ability to write

tall $=$ more than 1 sd taller than the mean

short $=$ more than 1 sd shorter than the mean

born pop $=$ population within $10 \mathrm{~km}$ of place of birth, thousands 
Table 3. Results: Were Tall Migrants Likely to Move Further? .regress dist_mig_if_mig_10 $10 \mathrm{~km}$ _not_lond
born_dist_from_blackfriars_ $\mathrm{km}$ _age_calc
heaping_only_birth_yr_known write_blank_no_total_height_inches
born_increm_1to10 if migrant_10km_not_london_born == 1

\begin{tabular}{|c|c|c|c|c|}
\hline Source & SS & $\mathrm{df}$ & MS & Number of obs $=6951$ \\
\hline Model | & 33062234.9 & 6 & 5510372.48 & Prob $>F$ \\
\hline Residual | & 79020138.3 & 6944 & 11379.6282 & R-squared \\
\hline Total | & 112082373 & 95 & 16126.9602 & Root MSE $=106.68$ \\
\hline
\end{tabular}

dist_mig_i $\sim$ d $\quad$ Coef. Std. Err. $\quad t \quad P>|t| \quad$ [95\% Conf. Interval]

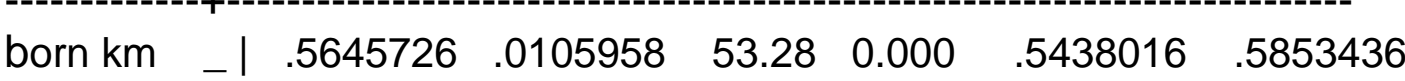
\begin{tabular}{l|lllllll} 
age & $\mid$ & .8170249 & .1856372 & 4.40 & 0.000 & .4531192 & 1.180931
\end{tabular} \begin{tabular}{l|llllll} 
heaping $\mid$ & -9.984688 & 7.270013 & -1.37 & 0.170 & -24.23614 & 4.26676
\end{tabular} \begin{tabular}{l|llllll} 
literacy & -4.700543 & 2.995881 & -1.57 & 0.117 & -10.57339 & 1.1723
\end{tabular} height $\quad \begin{array}{lllllll}2952676 & .4964639 & 0.59 & 0.552 & -.6779534 & 1.268489\end{array}$

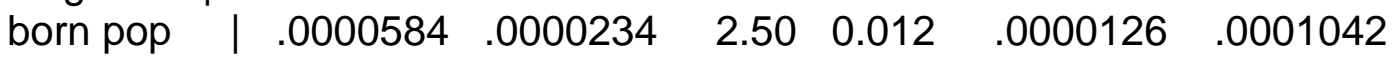

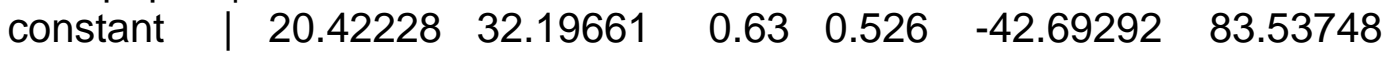

born $\mathrm{km}=$ distance of place of birth from London, in $\mathrm{km}$ age $=$ exact age, to the day when known heaping $=$ not knowing exact date of birth literacy = ability to write height $=$ height in inches born pop $=$ population within $10 \mathrm{~km}$ of place of birth, thousands 


\section{LONDON SCHOOL OF ECONOMICS}

\section{ECONOMIC HISTORY DEPARTMENT WORKING PAPERS}

(from 2002 onwards) For a full list of titles visit our webpage at

http://www.Ise.ac.uk/

\section{2}

WP67 Precocious British Industrialization: A General Equilibrium Perspective

N. F. R. Crafts and C. Knick Harley

WP68 Social Insurance Regimes: crises and 'reform' in the Argentine and Brazil, since c. 1900

Colin M. Lewis and Peter Lloyd-Sherlock

WP69 Can profitable arbitrage opportunities in the raw cotton market explain Britain's continued preference for mule spinning? Timothy Leunig

2003

WP70 The Decline and Fall of the European Film Industry: Sunk Costs, Market Size and Market Structure, 1890-1927 Gerben Bakker

WP71 The globalisation of codfish and wool: Spanish-English-North American triangular trade in the early modern period Regina Grafe

WP72 Piece rates and learning: understanding work and production in the New England textile industry a century ago Timothy Leunig

WP73 Workers and 'Subalterns'. A comparative study of labour in Africa, Asia and Latin America Colin M. Lewis (editor)

WP74 Was the Bundesbank's credibility undermined during the process of German reunification?

Matthias Morys 
WP75 Steam as a General Purpose Technology: A Growth Accounting Perspective

Nicholas F. R. Crafts

WP76 Fact or Fiction? Re-examination of Chinese Premodern

Population Statistics

Kent G. Deng

WP77 Autarkic Policy and Efficiency in Spanish Industrial Sector. An Estimation of the Domestic Resource Cost in 1958.

Elena Martínez Ruiz

WP78 The Post-War Rise of World Trade: Does the Bretton Woods System Deserve Credit?

Andrew G. Terborgh

WP79 Quantifying the Contribution of Technological Change to Economic Growth in Different Eras: A Review of the Evidence Nicholas F. R. Crafts

WP80 Bureau Competition and Economic Policies in Nazi Germany, 1933-39

Oliver Volckart

2004

WP81 At the origins of increased productivity growth in services.

Productivity, social savings and the consumer surplus of the film industry, 1900-1938

Gerben Bakker

WP82 The Effects of the 1925 Portuguese Bank Note Crisis Henry Wigan

WP83 Trade, Convergence and Globalisation: the dynamics of change in the international income distribution, 1950-1998

Philip Epstein, Peter Howlett \& Max-Stephan Schulze

WP84 Reconstructing the Industrial Revolution: Analyses, Perceptions and Conceptions of Britain's Precocious Transition to Europe's First Industrial Society Giorgio Riello \& Patrick K. O'Brien 
WP85 The Canton of Berne as an Investor on the London Capital Market in the $18^{\text {th }}$ Century Stefan Altorfer

WP86 News from London: Greek Government Bonds on the London Stock Exchange, 1914-1929

Olga Christodoulaki \& Jeremy Penzer

WP87 The World Economy in the 1990s: A Long Run Perspective Nicholas F.R. Crafts

\section{5}

WP88 Labour Market Adjustment to Economic Downturns in the Catalan textile industry, 1880-1910. Did Employers Breach Implicit Contracts?

Jordi Domenech

WP89 Business Culture and Entrepreneurship in the Ionian Islands under British Rule, 1815-1864

Sakis Gekas

WP90 Ottoman State Finance: A Study of Fiscal Deficits and Internal Debt in 1859-63

Keiko Kiyotaki

WP91 Fiscal and Financial Preconditions for the Rise of British Naval Hegemony 1485-1815

Patrick Karl O'Brien

WP92 An Estimate of Imperial Austria's Gross Domestic Fixed Capital Stock, 1870-1913: Methods, Sources and Results Max-Stephan Schulze

2006

WP93 Harbingers of Dissolution? Grain Prices, Borders and Nationalism in the Hapsburg Economy before the First World War

Max-Stephan Schulze and Nikolaus Wolf 
WP94 Rodney Hilton, Marxism and the Transition from Feudalism to Capitalism

S. R. Epstein

Forthcoming in C. Dyer, P. Cross, C. Wickham (eds.)

Rodney Hilton's Middle Ages, 400-1600 Cambridge UP 2007

WP95 Mercantilist Institutions for the Pursuit of Power with Profit. The Management of Britain's National Debt, 1756-1815

Patrick Karl O'Brien

WP96 Gresham on Horseback: The Monetary Roots of Spanish American Political Fragmentation in the Nineteenth Century Maria Alejandra Irigoin

2007

WP97 An Historical Analysis of the Expansion of Compulsory Schooling in Europe after the Second World War Martina Viarengo

WP98 Universal Banking Failure? An Analysis of the Contrasting Responses of the Amsterdamsche Bank and the Rotterdamsche Bankvereeniging to the Dutch Financial Crisis of the 1920s Christopher Louis Colvin

WP99 The Triumph and Denouement of the British Fiscal State:

Taxation for the Wars against Revolutionary and Napoleonic France, 1793-1815.

Patrick Karl O'Brien

WP100 Origins of Catch-up Failure: Comparative Productivity Growth in the Hapsburg Empire, 1870-1910

Max-Stephan Schulze

WP101 Was Dick Whittington Taller Than Those He Left Behind? Anthropometric Measures, Migration and the Quality of life in Early Nineteenth Century London Jane Humphries and Time Leunig 